\title{
Calculation on Social Co-ordination Account Payment Ratio of Pension Insurance of Urban Workers
}

\author{
Wei WANG \\ School of Finance and Public Management \\ Harbin University of Commerce \\ Harbin, China \\ E-mail:63993022@qq.com
}

\author{
Ya-Nan YANG \\ School of Economics \\ Harbin University of Commerce \\ Harbin, China \\ E-mail:yynmie@163.com
}

\begin{abstract}
Taking the maximizing personal utility and social welfare as the study perspectives, regarding the urban workers and state-owned enterprises as the research object, the ratio, $18.81 \%$, can be calculated by the model of social co-ordination account optimal payment ratio, which was lower than the current level of 1.19 percent. Furthermore, through applying feasibility analysis and sensitivity analysis of optimal payment ratio, we concluded it is feasible to decrease the social coordination account payment ratio moderately leading to government needs and social development.
\end{abstract}

Keywords-urban workers; pension insurance; social coordination account payment ratio

\section{INTRODUCTION}

With the development of Chinese economy and aging of population, the pension payment ratio has become the key issue of the reform of the pension insurance system. Aiming at the research on the payment ratio of pension insurance of urban workers, many scholars at domestic and abroad have studied from different angles. The study of foreign payment ratio is mainly embodied in the concept of payment and the forecast of future payment ratio, and they consider that the State should implement the pension insurance system combined with the pay-as-you-go system and fund accumulation system, propose the optimal payment ratio model under the pay-as-you-go system, and find that optimum payment ratio is related to the productivity, the ratio of population growth and the marginal product of capital [1-2]. The research on the domestic pension insurance is mainly embodied in the calculation of the social pension insurance payment ratio. Scholars have studied the internal factors such as pension substitution ratio and system maintenance ratio, analyzed the external factors such as the effective solution of historical debts, enriching the source of funds and raising the ratio of payment, raising the fund management. And they propose that China should reduce payment ratio and increase personal payment ratio, but the drastic reduction is not desirable [3-6]. This paper mainly based on the Thirteenth Five-year plan which propose to reduce the social pension payment ratio, calculated the social co-ordination account payment ratio of pension insurance of urban workers from the perspective of welfare maximization.

\section{OPtimal PAyMENT RATio MODEL OF PENSION INSURANCE OF SOCIAL CO-ORDINATION ACCOUNT OF URBAN WORKERS}

The pension insurance of urban workers is aimed at providing the social security after retirement, and satisfying every employee's needs, so we can consider that the optimal payment ratio of pension insurance from the perspective of personal utility and social welfare maximization. Assuming that the economy has three main bodies, employees, retirees and the government, the goal of workers is the maximization of life cycle utility, the goal of government is the maximization of social welfare, while the payment ratio which satisfy employee's life cycle utility and social welfare maximization is the optimal ratio.

\section{A. Objective Function of Workers and Government}

\section{1) Objective Function of Workers.}

Assuming that the personal utility is its consumption level function, the payment and prostrations of pension insurance change the consumption composition of worker's working period and retirement period, thus further influence their life cycle utility. Therefore, the function of consumption should be described before the objective function of workers is constructed. For simply research, this paper did not consider saving, therefore, under the system of basic pension insurance, the employee's consumption of working period equals the gross income subtract the personal account payment and the social co-ordination payment, the consumption of retirement period is composited by the personal account pension and the social co-ordination pension[7].

Under the system of basic pension insurance, the consumption of personal employees in t period is as following (1).

$$
C_{t, 1}=\left\{(1-\alpha-\beta) w_{t} A_{t}\right\}
$$

Where $\mathrm{t}$ is birth period, $C_{t, 1}$ is Consumption of single workers during t period, $\alpha$ is personal payment ratio, $\beta$ is social co-ordination account payment ratio, $\mathrm{w}_{\mathrm{t}}$ is unit effective labor of $\mathrm{t}$ period, $A_{t}$ is effective work of personal workers. 
The consumption of $t$ period of personal workers in the $t+1$ period is as following (2).

$$
C_{t+1,2}=\left\{\beta \lambda(1+g)(1+e) w_{t+1}+\alpha\left(1+r_{t}\right) w_{t}\right\} A_{t}
$$

Where $\mathrm{C}_{\mathrm{t}+1,2}$ is the consumption during $\mathrm{t}+1$ period of personal workers who retire in t period, $\lambda$ is ratio coefficient of wages, $g$ is population growth ratio, e is effective labors growth ratio, $r_{t}$ is interest ratio level in t period.

Assuming utility functions as logarithmic form is as following (3)

$$
U(C)=\operatorname{Ln} C
$$

The life cycle utility of a single worker in t period is as following (4).

$$
U_{t}=U_{1}\left(C_{t, 1}\right) v U_{2}\left(C_{t+1,2}\right)
$$

Where $v$ is the discount factor of personal future utility, $\mathrm{U}_{1}$ is utility of working, $\mathrm{U}_{2}$ is utility of retirement.

\section{2) Objective Function of Government}

The government is concerned about the interests of workers and retirees in the same period, and therefore, the objective function of government include the utility of workers and retirees, the goal is aim at maximizing social welfare.

Assuming the population of the $\mathrm{t}-1$ period is $\mathrm{L}_{\mathrm{t}-1}, \mathrm{t}$ period is $\mathrm{L}_{t}$, and the government target function is as following (5).

$$
W_{t}=L_{t}\left\{U_{1}\left(C_{t, 1}\right)+v U_{2}\left(C_{t+1,2}\right)\right\}+L_{t-1} U_{2}\left(C_{t, 2}\right)
$$

\section{B. Model of Social Co-ordination Account Optimal Ratio}

According to (4) and (5), we can get the model is as following (6).

$$
\beta=\frac{1+v(1+g)}{1+(1+v)(1+g)}\left\{1-\frac{a}{1-a} \cdot \frac{(1+v)(1+g)(1+e)}{\lambda(1+e)[1+v(1+g)]-v}\right\}
$$

where $\beta$ is social co-ordination account optimal ratio, $a$ is elasticity coefficient of capital output, $\mathrm{g}$ is population growth ratio, $v$ is the discount factor of personal future utility, e is effective labors growth ratio, $\lambda$ is ratio coefficient of wages.

\section{CALCUlations ON SOCIAL CO-ORDINATION ACCOUNT PAyMENT RATIO OF PENSION INSURANCE OF URBAN WORKERS}

\section{A. Data Acquisition and Parameter Selection}

\section{1) Population Growth Ratio}

Searching from China Statistical Yearbook, we obtained the population growth ratio was $14.39 \%$ in $1990,10.55 \%$ in
$1995,7.58 \%$ in $2000,5.89 \%$ in $2005,4.79 \%$ in 2010 , and $4.96 \%$ in 2015 . Therefore, in views of the aging population in China, the natural population growth ratio is set at $4 \%$.

\section{2) Effective Labors Growth Ratio}

In this paper the effective labor growth ratio equal to urban workers employment growth ratio, searching from the China Statistical Yearbook, we can see that the growth ratio of effective labor is in the range of $2.72 \%$ to $4.43 \%$, so take the average of 1996-2015 years, the effective labor growth ratio is $3.74 \%$.

\section{3) Discount Factor of Personal Future Utility}

The discount factor is closely related with the interest rate is as following (7).

$$
v=1 /(1+r)^{n}
$$

Where $\mathrm{n}$ is time interval between future and current, $\mathrm{r}$ is interest rate. Searching from China Statistical Yearbook, $r$ is set at $4 \%$. The statutory age of pension insurance in China is 15 years, because the pension insurance is different when their payment years exceed 15 years. Therefore, this paper set the payment year at 15, 20, 25, 30, 35, 40 years, according to the formula of discount factor to calculate six discount factors. The result is as following table1.

TABLE I. DISCOUNT FACTOR OF SIX KINDS OF PAYMENT YEARS

\begin{tabular}{|c|c|c|c|c|c|c|}
\hline $\begin{array}{c}\text { Payment } \\
\text { years }\end{array}$ & $\mathbf{1 5}$ & $\mathbf{2 0}$ & $\mathbf{2 5}$ & $\mathbf{3 0}$ & $\mathbf{3 5}$ & $\mathbf{4 0}$ \\
\hline $\boldsymbol{V}$ & 0.5553 & 0.4564 & 0.3751 & 0.3083 & 0.2534 & 0.2083 \\
\hline
\end{tabular}

\section{4) Elasticity Coefficient of Capital Output}

According to production function of Cobb-Douglas, the statistic value of industrial gross output, investment, and employee gross wages of state-owned enterprise from 1991 to 2014 can be returned to the contribution ratio of capital factor and labor factor of state-owned enterprises in China, the data of gross output value, investment and employee gross wages derived from Chinese Statistical Yearbook. After the logarithmic transformation of production function of CobbDouglas, we can obtained the function is as following (8).

$$
\begin{gathered}
\operatorname{Ln} Y=0.571885+0.321485 \operatorname{LnK}+0.779391 \operatorname{LnL} \\
(T)(0.977605) \quad(1.231699) \quad(2.288825) \\
R^{2}=0.982956 F=576.7001(p=0.0000) D W=0.511336
\end{gathered}
$$

According to the regression results, we can set the elasticity coefficient of capital output $a=0.32$.

5) Ratio Coefficient of Wages

In this paper, the ratio coefficient of wage in various regions in 2015 as an example, in which the ratio coefficient of wage is the ratio of the average wage of urban in each region and the average wage of the national. Searching from China Statistical Yearbook, we can obtain ratio coefficient of wages of 31 provinces and cities in 2015, as well as Q which is the number of urban workers, the results as shown in table2. 
TABLE II. RATIO COEFFICIENT OF URBAN WORKERS' WAGE AND NUMBER OF URBAN WORKERS IN 2015

\begin{tabular}{|c|c|c|}
\hline East & $\lambda$ & $\mathbf{Q}$ \\
\hline $\mathrm{BJ}$ & 1.795773 & 777.3 \\
\hline $\mathrm{TJ}$ & 1.29117 & 294.8 \\
\hline $\mathrm{HB}$ & 0.820922 & 643.6 \\
\hline SH & 1.760048 & 637.2 \\
\hline JS & 1.067178 & 1552.1 \\
\hline $\mathrm{ZJ}$ & 1.074788 & 1083.4 \\
\hline FJ & 0.929049 & 663.1 \\
\hline SD & 0.923278 & 1236.7 \\
\hline GD & 1.055376 & 1948.0 \\
\hline $\mathrm{HN}$ & 0.928598 & 100.4 \\
\hline West & $\lambda$ & $\mathbf{Q}$ \\
\hline NMG & 0.921101 & 298.3 \\
\hline GX & 0.854149 & 405.4 \\
\hline $\mathrm{CQ}$ & 0.976043 & 415.6 \\
\hline $\mathrm{SC}$ & 0.949798 & 795.5 \\
\hline$\overline{\mathrm{GZ}}$ & 0.962469 & 307.5 \\
\hline YN & 0.84741 & 414.7 \\
\hline $\mathrm{XZ}$ & 1.577472 & 33.4 \\
\hline$\overline{S X}$ & 0.886585 & 511.8 \\
\hline GS & 0.853504 & 261.8 \\
\hline $\mathrm{QH}$ & 0.984862 & 62.7 \\
\hline NX & 0.973416 & 73.1 \\
\hline $\mathrm{XJ}$ & 0.969176 & 317.2 \\
\hline Central & $\lambda$ & $\mathbf{Q}$ \\
\hline $\mathrm{SX}$ & 0.835142 & 440.3 \\
\hline $\mathrm{AH}$ & 0.888923 & 521.7 \\
\hline JX & 0.8211 & 465.3 \\
\hline $\mathrm{HN}$ & 0.731964 & 1125.9 \\
\hline HB & 0.876477 & 712.3 \\
\hline $\mathrm{HN}$ & 0.844073 & 579.1 \\
\hline Northeast & $\lambda$ & $\mathbf{Q}$ \\
\hline $\mathrm{LN}$ & 0.84367 & 618.4 \\
\hline JL & 0.831192 & 325.1 \\
\hline HLJ & 0.788035 & 433.5 \\
\hline National & $\lambda$ & $\mathbf{Q}$ \\
\hline & 1 & 18062.5 \\
\hline
\end{tabular}

\section{B. Calculation on Social Co-ordination Account Payment} Ratio of Pension Insurance of Urban Workers

The data of the above indexes are added to the formula (6), we can calculated different payment ratio in six kinds of payment years by Eviews8.0. The six kinds of payment ratio is $\beta_{1}, \beta_{2}, \beta_{3}, \beta_{4}, \beta_{5}, \beta_{6}$, and we took the number of urban workers of east, west, middle, and northeast as the weighted, and obtained the weighted average which were calculated by Eviews8.0 is as following table 3.

TABLE III. SIX KINDS OF PAYMENT RATIO AND AVERAGE RATIO

\begin{tabular}{|l|c|c|c|c|c|c|l|}
\hline & $\beta_{1}$ & $\beta_{2}$ & $\beta_{3}$ & $\beta_{4}$ & $\beta_{5}$ & $\beta_{6}$ & $\begin{array}{l}\text { averag } \\
\text { e }\end{array}$ \\
\hline Ratio & $\begin{array}{l}13.7 \\
2 \%\end{array}$ & $\begin{array}{l}16.5 \\
2 \%\end{array}$ & $\begin{array}{l}18.6 \\
3 \%\end{array}$ & $\begin{array}{l}20.2 \\
1 \%\end{array}$ & $\begin{array}{l}21.4 \\
2 \%\end{array}$ & $\begin{array}{l}22.3 \\
3 \%\end{array}$ & $18.81 \%$ \\
\hline
\end{tabular}

As can be seen in table 3, with the extension of payment years, the social co-ordination account payment ratio will be increased. And we can obtained the social co-ordination account payment ratio is $18.81 \%$ through the average of six kinds payment ratio. The current payment ratio of $19 \%$ is still higher than the optimum payment ratio 0.19 percent.

\section{FEASIBILITY ANALYSIS OF SOCIAL CO-ORDINATION ACCOUNT OPTIMAL PAYMENT RATIO}

Enterprises obtain sales revenue by selling products. Sales revenue includes intermediate inputs, value-added tax and added value, in which the added value is divided into capital remuneration and labor remuneration. Capital remuneration is divided into capital costs and profits, the source of enterprise pension insurance contributions to the industry profits. Therefore, the upper limit of the enterprise pension insurance payment is to make the enterprise profit all to pay pension insurance.

By the above, the increment value is $\mathrm{Z}$, the capital elasticity coefficient is a, the labor elasticity coefficient is $b$, then the capital reward of B is as following (9)

$$
B=Z \times a
$$

Labor remuneration of $\mathrm{W}$ is as following (10)

$$
W=\mathrm{Z} \times b
$$

Searching from China Statistical Yearbook, the cost ratio of depreciation and borrowing capital of state-owned industrial enterprises is about $40 \%$. Capital Cost of $\mathrm{C}$ is as following (11).

$$
C=B \times 40 \%
$$

Profit of $\mathrm{p}$ is as following (12).

$$
p=B-C
$$

The upper limit of payment ratio of $Q_{\text {upper }}$ is as following (13).

$$
Q_{\text {upper }}=p \div W
$$

Searching from China Statistical Yearbook, the average value-added rate of Chinese state-owned industrial enterprises is 0.337966 , that is, in 100 Yuan of the ex-factory price of products, the new value is 33.8 Yuan, and the intermediate input is 66.2 Yuan.

From the above, the capital elasticity coefficient of a is 0.32 , the labor elasticity coefficient of $b$ is 0.78 , namely in new value of 33.8 Yuan, the capital factor contribution is 10.816 Yuan, the employee wages is 26.36 Yuan, then the capital cost is 4.3264 Yuan, the enterprise profit is 6.4896 Yuan.

If the enterprise put 6.4896 Yuan of profit all to pay pension insurance of workers, then the basic pension insurance's highest affordability is $24.62 \%$. However, enterprises not only to pay the basic pension insurance for workers, but also need to pay medical, unemployment, maternity, occupational injuries and other social insurance. 
For example, the current unit payment ratio of social insurance is $31.1 \%$ in Beijing. This means that under the current social insurance system, the social insurance ratio paid by enterprises is higher than the upper limit of payment ratio 6.48 percent. Therefore, for the long-term survival and development of enterprises, as well as to alleviate the burden of enterprises, the State should consider moderate to reduce the payment ratio of basic pension insurance paid by enterprises.

\section{SENSITIVITY ANALYSIS OF SOCIAL CO-ORDINATION ACCOUNT OPTIMAL PAYMENT RATIO}

This paper assumed that some index data are constant, but the reality is not so. In order to test the robustness of the above results, this paper made a sensitivity analysis on the natural growth ratio of $g$, the effective labor growth ratio of e and the capital elasticity coefficient of a, and the results were shown in table IV. By table IV, the population natural growth ratio of $\mathrm{g}$ with the social co-ordination account optimal payment ratio are negative change, $\mathrm{g}$ increase or decrease 0.001 , resulting in $\beta$ decrease or increase $0.15 \%$ and $0.118 \%$. Effective labor growth ratio of e with the social co-ordination account optimal payment ratio is positive change, e increase or decrease 0.01 , resulting in $\beta$ increase or decrease $0.877 \%$ and $1.735 \%$. The capital elasticity coefficient of a with the social co-ordination account optimal payment ratio are negative change, an increase or decrease 0.01 , resulting in $\beta$ decrease or increase $10.334 \%$ and $9.496 \%$.

TABLE IV. SENSITIVITY ANALYSIS OF SOCIAL CO-ORDINATION ACCOUNT OPTIMAL PAYMENT RATIO

\begin{tabular}{|l|l|l|l|l|l|l|l|}
\hline $\begin{array}{l}\text { Param } \\
\text { eters }\end{array}$ & 15 & 20 & 25 & 30 & 35 & 40 & $\begin{array}{l}\text { Averag } \\
e\end{array}$ \\
\hline $\begin{array}{l}\mathrm{g}=0.3 \\
\%\end{array}$ & $\begin{array}{l}0.219 \\
\%\end{array}$ & $\begin{array}{l}0.182 \\
\%\end{array}$ & $\begin{array}{l}0.161 \\
\%\end{array}$ & $\begin{array}{l}0.14 \\
8 \%\end{array}$ & $\begin{array}{l}0.00 \\
0 \%\end{array}$ & $\begin{array}{l}0.000 \\
\%\end{array}$ & $0.118 \%$ \\
\hline $\begin{array}{l}\mathrm{g}=0.5 \\
\%\end{array}$ & - & - & - & - & - & - & - \\
& 0.146 & 0.121 & 0.161 & 0.14 & 0.18 & 0.134 \\
$\%$ & $\%$ & $8 \%$ & $7 \%$ & $0.150 \%$ \\
\hline $\mathrm{e}=2.74$ & - & - & - & - & - & - & - \\
$\%$ & 3.571 & 2.300 & 1.610 & 1.18 & 0.98 & 0.761 & $1.735 \%$ \\
& $\%$ & $\%$ & $\%$ & $8 \%$ & $0 \%$ & $\%$ & \\
\hline $\mathrm{e}=4.74$ & 1.968 & 1.211 & 0.805 & 0.59 & 0.37 & 0.313 & $0.877 \%$ \\
$\%$ & $\%$ & $\%$ & $\%$ & $4 \%$ & $3 \%$ & $\%$ & \\
\hline $\mathrm{a}=0.31$ & 15.08 & 11.38 & 9.232 & 7.91 & 7.00 & 6.359 & $9.496 \%$ \\
& $7 \%$ & $0 \%$ & $\%$ & $7 \%$ & $3 \%$ & $\%$ & \\
\hline $\mathrm{a}=0.33$ & - & - & - & - & - & - & - \\
& 16.39 & $\begin{array}{l}12.34 \\
9 \%\end{array}$ & $\begin{array}{l}10.09 \\
\%\end{array}$ & $\begin{array}{l}8.61 \\
0 \%\end{array}$ & $\begin{array}{l}7.65 \\
6 \%\end{array}$ & $\begin{array}{l}6.897 \\
\%\end{array}$ & $\begin{array}{l}10.334 \\
\%\end{array}$ \\
\hline
\end{tabular}

By table 4, the optimal payment ratio is indeed influenced by $\mathrm{g}, \mathrm{e}$ and a. And the sensitivity of personal optimal payment ratio is weaker to the change of $g$ and $e$, and the sensitivity to a change is stronger. Therefore, the rationality of the value of these variables needs to be fully considered before adjusting the optimum payment ratio.

\section{CONCLUSIONS}

Based on the maximization of personal utility and social welfare, this paper calculated the social co-ordination account optimal payment ratio of pension insurance of urban worker with a weighted average of $18.81 \%$, lower than the current level of 1.19 percent. Through applying the feasibility and sensitivity analysis of the optimal payment ratio, the measurement of the optimum payment ratio is influenced by the change of the related index, and it is feasible to decrease the payment ratio of social co-ordination account. This paper calculated the optimal payment ratio of pension insurance, referring to the research results of other scholars, assuming that some data indicators are fixed, therefore only consider the finite parameters, in the follow-up study we will be further comprehensive consideration, precise positioning, refinement analysis of relevant parameters, in order to obtain more reasonable social co-ordination account payment ratio of pension insurance.

\section{ACKNOWLEDGMENT}

This research was financially supported by National Social Sciences Fund under grant 14BJY032, Humanities and Social Sciences Fund of Ministry of Education under grant 12YJC790190, Postdoctoral Scientific Research Initiation under grant LBH-Q14094, LKY-2016jx-09 of CALSS in China.

\section{REFERENCES}

[1] Amy Rehder Social Security Benefit Uncertainty under Individual Accounts [J]ContemporaryEconomicPolicy.2005(23):1

[2] Thomas R.Michel \& Duncan k.Foley,social security in a classic growth model[J].Science Direct.2001(06)

[3] Wu Shurong. Brief discussion on the causes of urban workers' pension insurance fund gap and countermeasures [J]. Public Administration .2013 (12): 191

[4] Sun Yongyong, LI Weihan. From the rate of urban workers to see the basic old-age insurance system reform [J] China Population Science .2014 (5): 67-78

[5] Xian Mihua. Urban workers basic pension insurance fund revenue and expenditure of the status quo, problems and countermeasures [J]. Technological entrepreneurship .2015 (16): 18-20

[6] Bian Shu, Mu Huaizhong. Analysis of Optimal Contribution Rate of Personal Account in Liaoning Pension Based on Welfare Maximization [J].PopulationDevelopment, 2009(4):93.

[7] Niu Shuzhen, Liu Fang. Research on Optimal Contribution Rate Based on China's Basic Endowment Insurance System [J]. Business Research, 2007 (9): 65-66 